\title{
AGTERGRONDE VAN DIE EKUMENIESE BEWEGING
}

Prof. Dr. F. J. VAN ZYL

Karl Barth omskrywe die ekumeniese gedagte (in K.D. IV(3) 1 p. 37) as die gedagte van die eenheid van die kerke in die een kerk van Jesus Christus asook die strewe en wil daartoe. En as ' $n$ mens die agtergrond van hierdie beweging tot groter een-heid in die kerk van Christus wil aantoon, is jy tot 'n groot mate verplig om die voorgeskiedenis daarvan te beskrywe. Dit bring ' $n$ mens onmiddellik by die vraag na die begin- en eindpunt van jou beskrywing. Die omvattende werk wat onder die beskerming van die Ekumeniese Instituut van Bossey oor hierdie onderwerp die lig gesien het in 1954, en twee jaar gelede 'n tweede druk beleef het, (A History of the Ecumenical Movement) behandel die stof tussen 1517 en 1948 . Toe die Wêreldraad van Kerke op 6 September 1948 in Amsterdam vir die eerste keer saamgekom het, was dit 'n gebeurtenis van besondere betekenis in die geskiedenis van die kerk. Voorafgaande gebeurtenisse en ontwikkelinge wat op Amsterdam geintendeer was, is hier op 'n besondere wyse saamgevat en het 'n nuwe gestalte gekry, sodat 1948 'n gepaste eindpunt vir hierdie ondersoek is. Wat die beginpunt betref, wil ek my grotendeels beperk tot die vorige en die begin van ons eeu, en dit nie alleen vanweë die tydsbeperking waaraan 'n voordrag onderhewig is nie, maar ook omdat wat aan hierdie eeue voorafgaan grotendeeels die eenheidsstrewe van enkele individue en groepe was, sonder dat dit tot 'n werklike beweging uitgegroei het. Dit beteken geensins dat die eeue wat ons beginpunt voorafgaan, nie belangrik is vir ons tema nie. Trouens, 'n mens sal die gebeurtenisse van die 19de en 20ste eeu nie reg begryp as jy dit nie sien teen die breër agtergrond van veral die $17 \mathrm{de}$ en $18 \mathrm{de}$ eeu nie. Ons sal dan ook kortliks ons aandag aan daardie periode moet skenk, terwyl die hoofklemop die daaropvolgende eeue sal val.

Die vraag na die agtergronde van die ekumeniese beweging is bedoel om ' $n$ verklaring van hierdie beweging te gee, om moontlike oorsake vir sy ontstaan aan te toon. As Barth in sy tipering van die moderne kerkgeskiedenis (sedert die Renaissance) enkele opmerkings oor die ekumeniese gebeurtenis van hierdie tyd, dat die kerk nl. in 'n krisistyd as gevolg van 'n toenemende sekularisasie proses en 'n teologiese verval, juis in hierdie tyd, en veral in die 19de eeu, ontwaak het tot die aanvaarding van sy taak en roeping teenoor die wêreld soos nooit tevore nie. Terwyl die 
wêreld hom afwend van die kerk, word die profetiese amp van Christus in die kerk herstel op 'n tydstip toe dit nie verwag is nie. Barth lê natuurlik die grootste klem op die ontwaking van die kerk tot die aanvaarding van sy sendingsroeping, maar ook die ekumeniese beweging wil hy in die groot verband van die wending van die kerk na die wêreld sien. Dit sê hy is 'n feit wat 'n mens wel kan konstateer en beskrywe, maar histories kan dit nie verklaar word nie.

Daar word natuurlik verskillende uiterlike oorsake aangevoer vir die ontstaan van die ekumeniese beweging, of as 'n mens dit dan nie oorsake kan noem nie, dan wel faktore wat bevorderlik was vir 'n ekumeniese houding. Daaronder val faktore van diverse aard; politiek, ekonomies, sosiologies, intelektueel. In die 19de eeu het die volkere van Europa en Amerika hulle invloed grootliks uitgebrei in Afrika en Asië en ander dele van die wêreld waardeur die kerk ook vergroot geraak het en die vraag na kerklike eenheid ' $n$ ander toon aangeneem het. Die wêreld het deur die moderne kommunikasiemiddele kleiner en 'n groter eenheid geword waardeur hy ook geïnternasionaliseer geraak het. Die tyd van wêreldkonferensies breek aan. Die tyd van ontkerstening breek aan wat so 'n situasie skep dat die kerk alleen deur verenigde kragte die probleem die hoof sal kan bied. Sommige wil die ekumeniese beweging gebore laat word uit die nood van die wêreld en die kerk na die verwoestende en verbysterende eerste wêreldoorlog. Meer as ooit het in daardie sombere tyd die magteloosheid en versplintering van die kerk aan die dag gekom. Daar is andere wat die ontstaan van die ekumeniese beweging wil terugvoer na 'n diepere bewuswording van die wese van die kerk wat dan ook noodwendig die eenheid moet insluit. Maar hierteenoor maet opgemerk word dat die besinning van die kerk oor homself, sy wese, sy taak eers op 'n betreklike laat stadium in die ontwikkeling van die ekumeniese strewe gekom het, sodat dit beswaarlik as 'n agtergrond van die beweging gesien kan word.

Al sou 'n mens die ekumeniese beweging volgens Barth nie histories kon verklaar nie, moet jy ten minste 'n poging aanwend om hom te verstaan. En om dit te kan doen is daar een groot feit of faktor of agtergrond waarvan 'n mens nie kan loskom nie en dit is die invloed van die piëtistiese gees wat oorheersend was in die 19de eeu en tot uiting gekom het in opwekkingsbewegings oor groot dele van christelike Europa, Engeland en Amerika. Trouens, as ' $n$ mens die beslag wat die ekumeniese beweging in 1948 gekry het voorstel met die beeld van verskillende groter 
strome wat deur kleineres gevoed is en hier uiteindelik ineengevloei het, moet die piëtisme in die gestalte van die opwekkingsbewegings van die latere tye as die "reent" beskou word wat tot die vorming van die verskillende strome gelei het. En terwyl hierdie beeld genoem is, kan ook nog verder gemeld word, dat alhoewel die ineenvloeiing in Nederland geskied het, die grootste getal voedende stroompies en derhalwe die eintlike opvangsgebied in die Angelsaksie wêreld was. Daar is byna geen beweging, organisasie, genootskap of vereniging van wyer as plaaslike verband wat in hierdie tyd ontstaan het, waarvan die oorsprong nie teruggevoer kan word tot piëtistiese invloed nie. As reaksie teen die starre en abstrake rasionalisme van die Aufklärung met die klemverskuiwing van die rede na die gevoel en die ervaring, is die piëtisme verstaanbaar. En alhoewel die piëtisme homself beskou het as 'n tweede reformasie, wat dit die teendeel van Reformatoriese reformasie. Want hier het dit nie gegaan om 'n nuwe gehoorsame luister na die Woord van God nie, maar om die woordlose ontdekking van eenheid en identiteit met die oneindige in die eiedieptes van die mens self, nl. in die gevoel. Vernuwing van die kerk geskied nie deur nuwe gehoorsaamheid aan die Woord van God nie, maar deur die wedergeboorte van alle christene: eers van die predikante en dan van die gewone lidmate. Wedergeboorte skep 'n nuwe gemeenskap, en bring 'n onsigbare, geestelike kerk tot stand wat die ware kerk is en wat die grense van die konkrete, historiese kerke oorskrei. In die piëtisme gaan dit om religieuse onsigbare en vir die ware christene is die eenheid van die ware kerk dan ook geleë in die eenheid van ervaring. Maar hierdie onsigbare, ware kerk, en gevolglik ook sy eenheid, kan volgens Zinzendorf sigbaar word in die wêreld se oë, $\mathrm{nl}$. in die gemeenskap (fellowship) van sy lede. Die piëtisme is in hierdie opsig alleen maar konsekwent, want as die Woordverhouding afgesny word, verval die geloofsgemeenskap en word vervang deur 'n ervaringsgemeenskap. Eintlik kan nie meer van gemeenskap gepraat word nie, maar van bymekaarwees, van „togetherness". Die eenheid van die kerk is nou geleë in die bymekaar-wees van individue met dieselfde ervaring. Dit is ook verstaanbaar waarom die piëtisties georiënteerde godsdienstigheid so gesteld is op die bymekaar-wees van eenders voelendes. Brunner het meermale daarop gewys dat die mistieke gevael van eenheid met die absolute die mens laat vereensaam omdat hy in die diepste grond slegs 'n monoloog voer. Die bymekaarwees van eensames kan die ware eensaamheid wel nie ophef nie, maar tog tot 'n mate verligting bring. ' $n$ Kenmerk van die 19de eeu is dan ook die 
talle vrywillige organisasies wat ontstaan het op die inisiatief van individuele christene uit die opwekkingstye. Die christelike kameraadskap wat beleef is op internasionale byeenkomste het die deelnemers beindruk, en hier het die visie ontstaan van 'n eendragtige kerk. So wat dit die geval met Söderblom, die reus onder die yweraars vir die ekumeniese gedagte en strewe. Op 'n byeenkoms van die Wêreldfederasie van christelike studente in Northfield, Amerika, 1890, teken hy die volgende gebed in sy sakboek op: Heer, gee my deemoed en die wysheid om die groot saak van die vrye eenheid van U kerk te dien. Veral hierdie Wêreldfederasie van christenstudente, maar ook ander wêreldbonde en -organisasies, het 'n belangrike bydrae gelewer, en kan ook beskou word as voorbereiders van die ekumeniese beweging. Kerklike leiers oor die wêreld het op hierdie organisasies se byeenkomste mekaar ontmoet en leer ken en so kan hulle beskou word as die leer- en oefenskole van die latere ekumeniese leiers. 'n Mens kan feitlik enigeen van die wêreldverenigings op een of ander wyse in verband brig met die ekumeniese beweging. Enkeles wat verdien om genoem te word is: Die Evangeliese Alliansie wat in 1846 in Londen vergader het en deur nie minder as 800 kerkleiers oor die wêreld bygewoon is nie. Hierdie alliansie bepleit die eenheid van die kerk en het o.a. aan die begin van elke jaar 'n gebedsweek aan hierdie tema gewy. Verder die wêreldbond van Sondagskole, samekoms in Londen 1889; en die reeds genoemde Wêreldfederasie van christenstudente. Die betekenis van hierdie en baie ander organisasies was dat dit die kerke internasionaal bewusgemaak het van mekaar. Die 19de eeu beleef dan ook die ontstaan van die verskillende internasionale konfessionele wêreldbonde wat ongetwyfeld ook 'n groot bydrae gelewer het om die ekumeniese klimaat te skep:

Die Lutherane. 1866

Anglikane - Lambeth Conference 1867.

Presbiteriane 1877.

Metodiste 1881.

Baptiste 1905.

Oud Katolieke 1889.

Nadat ek die breër agtergrond waarteen die ekumeniese b? weging gesien en verstaan moet word nou aangetoon het, wil ek verder die meer direkte wortels ontbloot wat gelei het tot die bepaalde gestalte wat die beweging in 1948 aangeneem het. Ek beperk my tot na my oordeel die drie belangrikstes: 
1) Die Wêreldsending.

2) Die beweging vir Geloof en Kerkorde.

3) Die beweging vir Lewe en Werk.

\section{1) Die wêreldsending.}

Hoewel die sending eers met die derde byeenkoms van die Wêreldraad van Kerke, in 1961 te Nu-Delhi, in die ekumeniese stroom van 1948 gevloei het, moet hy tog beskou word as een van die belangrikste faktore wat 'n besondere stootkrag verleen het tot die ontstaan van die ekumeniese beweging. As leier van die nuwe 19de eeuse sendingsbeweging wat sy stoot gekry het van die piëtisties-geïnspireerde opwekking, moet William Carey genoem word wat in 1792 die Baptiste Sendinggenootskap gestig het, en met sy wêreld-sendingprogram begin het. 'n Brief van hom uit die Indiese sendingsgebied het 'n groepie opwekkingsvriende so aangegryp, dat hulle in 1795 oorgegaan het tot stigting van die bekende en in ons land land berug-geworde Londense Sendinggenootskap. Die interkonfessionele tendens wat so kenmerkend van die opwekkingstyd was, word deur hierdie genootskap tot prinsiep verhef by die uitvoering van die sendingtaak, insoverre geen kerklike gestalte, nog die presbiteriaanse, nog die biskoplike aan die heidene gebring sou word nie, maar slegs „die heerlike evangelie van die hooggeprese God". Carey se aanvanklike oogmerk was om die evangelie aan die heidene denominasioneel te bedien, maar na 'n kort verblyf in Indië het hy van sienswyse verander. Hy stel dan ook ' $n$ interkonfessionele wêreldkonferensie om die tien jaar voor, en beveel aan dat die eerste daarvan in Kaapstad gehou sal word in 1810. Om verskillende redes is hierdie konferensie nie gehou nie, maar 'n derglike is 'n eeu later in Edinburgh gehou wat vir die sending sowel as vir die ekumeniese gedagte van groot betekenis gewees het. Eintlik moet hierdie konferensie in die lyn van William Carey gesien word, en die voortsetting en bekroning van wat deur die Union Missionary Convention in 1854 in New York begin is. Hier het verskillende sendinggenootskappe vir die eerste keer saamgekom, en dis opgevolg deur andere te Liverpool 1860, New York 1900, waar die woord ekumenies vir die eerste keer gebruik is.

Teenoor sy voorgangers was die byeenkoms te Edinburgh om verskillende redes 'n vooruitgang. Hoewel die konferensie grotendeels nog deur sendinggenootskappe verteenwoordig was, en die grootste getal van sy lede uit die Anglo-Amerikaanse gebied was, was hulle afgevaardigdes van genootskappe wat offisiële liggame van kerke was en derhalwe kerkgesind. Die konferen- 
sies wat op hierdie een gevolg het het kerk en sending al nader aan mekaar gebring totdat hulle in 1938 mekaar te Tambaram vir goed gevind het. Waar die vorige byeenkomstes van hierdie aard bedoel was om indruk te maak op die publiek en steun te soek vir die sendingonderneming, was hierdie een meer van konsulterende aard en is planne beraam vir gesamentlike optrede in die toekoms. Op hierdie konferensie was verteenwoordigers van die jong kerke vir die eerste keer verteenwoordigers as profetiese teken van die rol wat hulle later in die ekumeniese beweging sou speel. Hoewel dit op die konferensie net om samewerking en saambeplanning vir die toekoms gegaan het, is baie stemme tog gehoor vir groter eenheid. Latourette sê van die konferensie: Edinburgh 1910 marked a new sense of fellowship among christians. Mott het in sy sluitingstoespraak melding gemaak van die feit dat die afgevaardigdes tot die besef van hulle "one-ness in Christ" gekom het. Nooit tevore was daar so 'n wye verteenwoordiging van die wêreldwye christendom nie wat baie rasse, nasies en geloofsskakeringe ingesluit het. 'n Gemeenskap in Christus is egter ontdek wat alle skeidsmure tebowe gegaan het. ,The growing realization of this fellowship was to be one of the most significant characteristics of the ecumenical movement". 'n Belangrike gebeurtenis op hierdie konferensie was die verkiesing van 'n voortsettingskomitee, wat geen geringe bydrae gelewer het tot die organisasie van die ekumeniese beweging soos hy later ontwikkel het nie. In 1921 is die I.S.R. gestig wat voortaan die konferensies sou reël: Jerusalem 1928, Tambaram 1938, Whitby 1947. Waar Edinburgh nog grootliks die byeenkoms van sendinggenootskappe was wat die gees van die piëtisies-metodistiese opwekkingsbewegings geadem het en los van die kerk gestaan het, het kerk en sending mekaar nie alleen ontmoet op die volgende konferensies nie, maar ook sending en teologie. Sending en kerk het albei tot noodsaaklike en heilsame selfbesinning gekom. 'n Ander teologiese wind het ook reeds oor die wêreld begin waai wat die vraag na die kerkwees van die kerk met erns gevra het. En hoewel die piëtistiese invloed daardeur nie meteens en geheel uitgesuiwer is uit die ekumeniese gedagte nie, het die diepere teologiese besinning wat daar op die sendingkonferensies gekom het tog 'n wesenlike bydrae gelewer tot 'n meer Bybelsverantwoorde ekumeniese beskouing.

Edinburgh 1910 was nog in 'n ander opsig belangrik. Dit het die stoot gegee aan 'n beweging wat later een van die hoofstrome van die ekumeniese beweging geword het, $\mathrm{nl}$. 


\section{2) Die beweging vir Geloof en Kerkorde.}

Die Edinburgh konferensie het 'n breër verteenwoordiging van kerklike aard gehad as sy voorgangers. Dis voorafgaande byeenkomstes is grotendeels bygewoon deur besliste protestante, terwyl altyd 'n redelike afkeer geheers het teenoor mense van katolieke tradisie, soos die Anglikane (Anglo-Catholics). Maar op Edinburgh was hulle teenwoordig op voorwaarde dat sake van geloof en kerkorde nie bespreek sou word en geen besluit daaroor geneem sou word nie. Biskop Charles $\mathrm{H}$. Brent van die Protestant Episcopal Church het tydens die kongres dit egter as sy oorwoë mening uitgespreek dat die kongres deur hierdie besluit of voorwaarde homself die reg ontsê het om een van die mees fundamentele sake te bespreek waarmee christene gekonfronteer is. Vir hom kon dit nie slegs om samewerking van geskeie liggame gaan nie, maar daarom dat die oorsake van die skeiding ondersoek word met die oog op die verwydering daarvan. Hy het dan ook sy voorneme te kenne gegee om iets aan die sáak te doen. Hy het dit gedoen in Oktober van dieselfde jaar toe ' $n$ algemene vergadering van sy kerk die volgende mosie aangeneem het: dat 'n kommissie benoem word wat 'n konferensie sal saamroep om vrae i.v.m. geloof en kerkorde te oorweeg en dat alle christelike gemeenskappe dwarsdeur die wêreld wat Jesus Christus as Heer en Saligmaker bely, gevra sal word om hulle met die poging te verenig met die doel om 'n konferensie te organiseer en te hou. En so het Brent gestalte gegee aan die visioen van die eenheid van die kerk wat hy op Edinburgh gekry het. Die komitee het onmiddellik kontak begin maak met die kerke van die wêreld. 'n Groot vertraging is veroorsaak deur die eerste wêreldoorlog wat nuwe bitterheid gebring het onder christene wat reeds op kerklik-godsdienstige gebied verdeeld was. Veral die Anglo-Amerikaanse leiers het die nasies wat oorwin is vir 'n lang tyd nie regtig vertrou nie. Na die oorlog is die organisasie voortgesit totdat die eerste konferensie in 1927 in Lausanne saamgekom het. Op die basis: Jesus Christus as God en Heiland, en onder die besielende voorsitterskap van Brent het 400 verteenwoordigres van 108 kerke vergader om oor verskillende temas te beraadslaag, soos:

Die roeping tot eenheid.

Die wese van die kerk.

Die boodskap van die kerk aan die wêreld.

Die eenheid van die kerk en die houding van die bestaande kerke daartoe, ens.

Die bedoeling was om vas te stel oor watter geloofspunte daar 
die meeste verskil van opvatting bestaan, dit dan nader te ondersoek en riglyne vir groter eenstemmigheid aan te dui. Die gevaar van die konferensie was dat te gou skynbare ooreenstemming bereik is oor die groot verskille. Die vergadering het dit egter ingesien en besluit dat die verskillende rapporte nie aangeneem sal word nie maar alleen aanvaar sal word vir deursending en behandeling deur die onderskeie verteenwoordigde kerke. Feitlik dieselfde vrae is op die tweede vergadering van hierdie organisasie behandel te Edinburgh in 1937. Op hierdie konferensie en die wat later gevolg het, ontwikkel die metode van hierdie beweging en word dit al duideliker dat die konferensies gespreksplekke word, plekke vir gedagtewisseling, uitwisseling van raad en wedersydse geestelike steun in die aangesig van gemeenskaplike vrae.

Op die Lausanne konferensie was daar een rapport wat nie aangeneem is nie, $\mathrm{nl}$. die een oor die Eenheid van die Kerk en die verhouding van die bestaande kerke daartoe. In hierdie rapport wat o.a. deur Söderblom, aartsbiskop van Uppsala, opgestel is word 'n sterk pleidooi gelewer vir praktiese samewerking. Die beswaar het veral van die Anglikaanse groep gekom wat in die pleidooi vir praktiese samespreking 'n ekumeniese opvatting gesien het wat alleen ten koste van die eenheid in geloof en kerkorde aanvaar kan word. Vir die Anglikane het dit meer om kerkorde, om organiese eenheid as om geloof gegaan, en vir hulle was die konferensie van Lausanne 'n groot teleurstelling. Hierdie uitval van die Anglikane met die pleitbesorgers van interkerklike samewerking bring ons by die tweede hoofstroom in die ekumeniese beweging $\mathrm{nl}$.

3) Die beweging vir Lewe en Werk, waarvan Söderblom die groot leier en krag was. Die beweging vir Lewe en Werk het ontstaan uit die Wêreldbond vir vriendskap tussen die Volke deur die kerke; 'n beweging wat hom op wêreldvrede toegelê het. Dit was geen kerklike organisasie nie, maar 'n beweging wat begin is deur leidende figure wat met die wêreldpolitiek te doen gehad het en wat baie besorgd was oor die toestand in die wêreld voor die eerste oorlog. Politieke figure soos Dickinson en Siegmund Schultze het Duitse en Engelse teoloë bymekaar gebring in die sg. Church Peace Union wat bogenoemde wêreldbond kort voor die eerste wêreldoorlog in Constanz, 1914, gestig het. Op 'n vergadering van hierdie Bond te Oud Wassenaar, Den Haag, 1919, kom Söderblom, as tolk van baie kerke, met die plan van 'n permanente raad van die christenheid. Veral die oorsake van die oorlog moes opgespoor en veroordeel word. 'n Konsilie word 
in die vooruitsig gestel waar nie gepraat sou word oor die verdeelde kerk nie maar oor die toepassing van die evangeliese beginsels op die sosiale, ekonomiese en internasionale lewe. Behalwe sy groot hartstog vir kerklike eenheid was Söderblom veral begaan oor wêreldvrede en oor die saak van die sosiale geregtigheid Die algemene christelike raad vir praktiese christendom waarvan Söderblom op Oud Wassenaar gepraat het en ook gevorm is, het saam met die wêreldbond vir wêreldvrede die ekumeniese konferensie vir Lewe en Werk georganiseer, wat in 1925 in Stockholm saamgekom het. 660 afgevaardigdes van kerke uit die hele wêreld was op die konferensie teenwoordig wat deur Söderblom gedra is. Dit gaan in hierdie beweging om praktiese samewerking van die kerke t.o.v. ekonomiese, industriële, sosiale en sedelike vrae. Tereg is hierdie konferensie die Nicea van die etiek genoem. By die Internasionale sosiaalwetenskaplike Instituut te Geneve word die eintlike werk van hierdie bewering verrig. Dit gaan om die studie van sosiale en ekonomiese feite en probleme in die wydste sin van die woord, in die lig van die christelike etiek volgens streng wetenskaplike metodes en om sodoende die normatiewe beginsels vir praktiese handeling vas te stel.

Die grondgedagte wat op hierdie eerste konferensie geheers het was dat 'n mens ondanks geloofsverskille tog prakties kan saamwerk en 'n sosiale getuienis kon lewer. Oor sake van geloof en leer sou daar nie gepraat word nie, want die slagspreuk was: leer skei - diens verenig. Maar die ekumeniese grondvergissing van Söderblom en die konferensie was geleë in die opvatting dat eenheid in geloof en eenheid in liefde teenstellings sou wees. Hier is die fides qvae (geloofsinhoud) en die fides qva (geloofsvertroue) teenoor mekaar gestel. Die konferensie was tot 'n baie groot mate teleurstellend. Daar het 'n diep kloof gegaap tussen die vastelandse en Engels-Amerikaanse afgevaardigdes. Die teologiese beswaar teen hierdie konferensie is egter later ingesien en op die volgende byeenkoms te Oxford 1937 agterhaal.

Die betekenis van die konferensies van Geloof en Kerkorde en van Lewe en Werk, moet ons sien in die feit dat die kerke met mekaar in gesprek getree het en wel al meer sistematies en sodoende die weg na groter eenheid gesoek het. Namate die besinning meer sistematies geword het kom daar ook 'n diepere begrip van die ekumeniese beweging self $\mathrm{Al}$ meer en meer het daar duidelikheid en ooreenstemming gekom oor die eintlike doel met die beweging.

Al meer en meer word dit duidelik dat die beweging in niks 
anders gefundeer kan wees as in die wese van die kerk self nie. Waar lewe en werk, geloof en kerkorde: die praktiese en teoretiese, die doel en die basis, aanvanklik nog van mekaar geskei was en ook doelbewus uitmekaar gehou is, het hierdie twee strome al nader na mekaar beweeg totdat hulle op die onderskeie konferensies van Edinburgh en Oxford, 1937, besluit het om in ' $n$ wêreldraad van kerke saam te vloei. Die gebeurtenisse wat tot die vorming van genoemde wêreldraad van kerke direkte aanleiding gegee het, was die volgende: in 1933 word 'n vergadering van 10 amptenare van ekumeniese liggame gehou wat deur aartsbiskop Temple saamgeroep is te Bishopthorpe. In 1937 word 'n vergadering van 35 kerkleiers gehou in Westfield College, Hampstead. Uit hierdie twee vergaderings kristalliseer drie oortuigings:

a. dat die ekumeniese beweging alleen kan slaag as dit 'n beweging van die kerke is wat in hulle lewe gegrond is;

b. dat die tyd ryp is vir 'n permanente verband tussen die kerke wat die volgende twee aspekte van die ekumeniese situasie moet uitdruk:

i) dat organiese eenheid onmoontlik is as gevolg van die verskil in geloof en kerkorde, maar

ii) dat hulle begeer om in 'n gemeenskap van gesprek, samewerking en onderlinge hulp te tree;

(iii) dat Geloof en Kerkorde, Lewe en Werk wedersyds afhanklik van mekaar is en mekaar noodwendig aanvul.

Die vergadering van Westfield besluit om die volgende aanbeveling deur te stuur na die konferensies van Lewe en Werk en van Geloof en Kerkorde wat in Edinburgh en Oxford gehou staan te word: dat met die oog op doeltreffender aksie van die christelike kerke in die moderne wêreld, die genoemde twee bewegings nouer met mekaar verbind word in 'n liggaam wat verteenwoordigend van die kerke sal wees en wat na die belange van elkeen van die bewegings sal omsien. Oxford en Edinburgh neem albei die voorstel aan en benoem elkeen 7 lede om die nuwe Wêreldraad te vorm. Die vergadering van $\mathrm{G}$. en $\mathrm{K}$. het een voorwaarde gestel, nl. dat die werk van G. \& K. volgens sy hoofbeginsels gewaarborg sal word in die nuwe raad. Daarom kom hierdie beweging na die stigting van die Wêreldraad van Kerke nog altyd afsonderlik byeen. Die nuwe raad het 'n breër adviserende raad uit die kerke naas hom gevorm. In 1938 is die konsepkonstitusie vir die Wêreldraad opgestel in Utrecht en met uitnodiging na die eerste algemene vergadering wat vir 1941 beplan is, na die ver- 
skillende kerke gestuur. Die tweede wêreldoorlog verydel hierdie voorneme. Eers in 1947 kon die algemene vergadering van die Wêreldraad voorberei word. Oor sy aard is uitdruklik gesê dat elke gedagte ontken word om van die Wêreldraad 'n verenigde kerk te maak wat deur 'n gesentraliseerde administratiewe gesag gedomineer sou word. Sy doel is slegs om die kerke te dien as 'n liggaam waardeur hulle tesame getuienis kan lewer van hulle gemeenskaplike geloof en saam kan werk in sake van gemeenskaplike aksie. En so het die eerste vergadering op 6 September 1948 in Amsterdam saamgekom. Die Wêreldraad van Kerke het ' $n$ werklikheid geword. Die ekumeniese beweging het 'n nuwe fase ingegaan. Op hierdie eerste vergadering was ons Kerk deur ds. T. F. J. Dreyer verteenwoordig. Met hoë verwagtings van die ekumeniese beweging het ons kerk aangesluit en kon hy aansluit totdat hy enkele jare gelede sy lidmaatskap van hierdie liggaam opgesê het. Die rede vir hierdie stap is die verhaal na 6 September 1948.

1.-

\section{GERAADPLEEGDE LITERATUUR}

Dr. H. van der Linde, De Wereldraad van Kerken, 1948.

World Council of Churches, Minutes and Reports of the Meeting of the Provisional Committee, Buck Hill Falls. Penn., April 1947.

Dr. C. J. Bleeker e.a., De Oecumenische Beweging, Nederlandsch Jeugcomité. 1935.

Lucas Vischer, A Documentary History of the Faith and Order Movement 1927-1963. The Bethany Press, St. Louis, Missouri, 1963.

World Council of Churches, The Ten Formative Years 1938-1948, Geneve.

Ruth Rouse and S. C. Neill, A History of the Ecumenical Movement 16171948. 2nd ed., London 1967.

Karl Barth, K.D. IV/3(i). 